\title{
Institutions and Managerial Task Allocation: Evidence from Chinese Entrepreneurs
}

\author{
Di Guo \\ University of Hong Kong \\ Kun Jiang \\ University of Roehampton \\ Chenggang $X_{U}$ \\ Cheung Kong Graduate School of Business
}

\begin{abstract}
This study presents theoretical and empirical analyses of the time allocation of entrepreneurs as a response to weak property rights protection. Using a nationwide random-sample survey of more than 3,000 entrepreneurs in over 100 cities in China, we find that entrepreneurs, responding to the violation of property rights, spend large proportions of their working time on lobbying activities to protect their businesses at a cost to management time. Moreover, the sensitivity of lobbying time to property rights protection is reduced if the entrepreneur is politically connected or if the firm is larger or older.
\end{abstract}

These ex-communist countries are advised to move to a market economy . . . but without the appropriate institutions no market economy of any significance is possible... . [T] he interrelationships which govern the mix of market and hierarchy . . . are extremely complex. ... What we need is more empirical work.

(Coase 1991)

\section{Introduction}

Institutions, specifically property rights and contracting institutions, are regarded as conditions that enable markets to function (Smith [1776] 1981;

We acknowledge comments from the Conference Honoring Nobel Laureate Ronald Coase on Receiving Honorary Doctorate from the State University of New York at Buffalo, two referees, and in particular Sam Peltzman. We follow the Coasian tradition, which refers to his view that economics is a study of the economy as it actually operates in the real world, and his approach to empirical work, which focuses on understanding a variety of unknown institutions

[ Journal of Human Capital, 2017, vol. 11, no. 3]

(c) 2017 by The University of Chicago. All rights reserved. 1932-8575/2017/1103-0005\$10.00 
North 1981). Although conceptual or theoretical arguments have been presented, systematic evidence became available only recently. Empirical studies show that stronger property rights protection and contract enforcement promote firm performance, enhance corporate governance and corporate innovation (La Porta et al. 2000; Klapper and Love 2004), and encourage firm growth and reinvestment (Besley 1995; Johnson, McMillan, and Woodruff 2002; Cull and Xu 2005), thereby promoting economic growth (Acemoglu, Johnson, and Robinson 2001; Acemoglu and Johnson 2005). Most studies analyze the effect of institutions on the performance outcomes or strategies of firms, but little is known about a more basic mechanism for the effects of institutions on the effort exertion of entrepreneurs.

This study attempts to fill this knowledge gap; that is, we analyze entrepreneurs' responses in their time allocation to institutional constraints, particularly the insecurity of private property rights, on the basis of a nationwide random-sample survey conducted in China. The data set we use covers detailed information on the time allocation of entrepreneurs and distinguishes among their time devoted to work and leisure and time allocated to different activities at work. We analyze the relationships of institutional constraints with the time devoted to management and lobbying activities by decomposing time allocation of entrepreneurs at work.

In this paper, "lobbying" means activities seeking to influence local governments to protect the businesses of individual entrepreneurs, and it is not about influencing legislators or lawmaking. In China, entrepreneurs are not allowed to organize themselves for political representation independently from the party-state, which makes decisions on laws and regulations. Therefore, the lobbying activities of entrepreneurs mainly target the arbitrary decisions of local governments, which are not subject to rules or laws, to protect their own businesses.

Time allocation is critically important for entrepreneurs of small- and medium-sized enterprises (SMEs). Becker (1965) and the follow-up literature focus on the trade-offs that individuals make between work and leisure, that is, working- versus nonworking-time allocation. ${ }^{1}$ However, the process involved in allocating time within the working time of entrepre-

\footnotetext{
and their influences. Financial support from the Research Grants Council (RGC) ThemeBased Research Scheme (project T31-717 112-R) and the RGC General Research Fund (project 756711) are acknowledged. All errors are our own.

${ }^{1}$ Becker (1965) introduces the "household production function," which studies the substitution effect of the growth in productivity of working and its trade-off with consumption time loss. However, Pollak and Wachter (1975) argue that joint production results in the confounding of tastes and technology within shadow prices. Empirical studies indicate that self-employed people report higher job satisfaction than regular employees even when they work longer hours and earn lower wages than employees (Benz and Frey 2004). At the same time, despite their lower pay and rate of promotion, women are more satisfied with their jobs than men (Clark 1997). Social norms and peer pressure may also affect an individual's time allocation to paid work, voluntary work, and leisure (Freeman 1997; Fehr and Falk 2002; Akerlof and Kranton 2005).
} 
neurs has received significantly less attention. This issue is particularly relevant to entrepreneurs of SMEs, who normally have less developed management teams and social networks. Balancing the efforts exerted on different activities is important for entrepreneurs because it could determine the survival and growth of firms. In the few studies on the time allocation of entrepreneurs, ${ }^{2}$ the effects of institutions on time allocation of entrepreneurs are largely ignored in economics literature.

Interaction between institutions and time allocation is important, as institutions influence entrepreneurs' trade-offs when they allocate their time and efforts among different tasks (Holmstrom and Milgrom 1991; Dewatripont, Jewitt, and Tirole 1999, 2000), ${ }^{3}$ particularly among productive and nonproductive activities. A major premise of the multitask theory is that all efforts of individuals at work are productive. However, this presumption does not necessarily stand when entrepreneurs face institutional impediments that distort the time allocation of talents (Acemoglu 1995; Acemoglu, Johnson, and Robinson 2005) and affect their efforts in daily work. Entrepreneurs are induced to pursue rent-seeking rather than creating new knowledge or products because they have to spend time lobbying to gain government-controlled resources (Tullock 1967; Baumol 1990). However, studies on the interaction between institutions and multitask issues are restricted to theory. To our knowledge, no systematic empirical study has investigated the relationships between institutions and time allocation to management and lobbying efforts.

China provides an interesting case for studying trade-offs (costs and benefits) faced by entrepreneurs when they allocate time to different tasks to address institutional impediments. The private sector ${ }^{4}$ in China began from scratch in the 1990s because it was completely illegal not long ago. Thanks to rapid growth and privatization, the private sector now comprises approximately 40 million registered private businesses and 34.07 million individually owned businesses. These businesses accounted for more than half of China's GDP by the end of 2010. Private property rights are fully legalized in principle since the constitutional amendments of 2004. Allowing and recognizing private property rights are important improvements over previous conditions, explaining a large part of China's growth.

\footnotetext{
${ }^{2}$ McCarthy, Krueger, and Schoenecker (1990) and Fischer and Reuber (1997) examine the changing time-allocation patterns of entrepreneurs as firms move from one stage of development to another. Cooper, Ramachandran, and Schoorman (1997) find that craftsmenentrepreneurs devote less time to administrative activities than entrepreneurs with managerial experience. Verheul, Carree, and Thurik (2009) find that female entrepreneurs invest less time in the business than male entrepreneurs.

${ }^{3}$ Lucas and Moll (2011) study the effects of multitasking on growth. In their model, agents divide their time between production and learning activities, which determine real economic growth.

${ }^{4}$ A narrowly defined private sector refers to registered private businesses and individually owned businesses. A broadly defined private sector refers to all non-state-owned enterprises, including the narrowly defined private businesses, collectively owned enterprises, and foreign enterprises. In this study, we focus on the narrowly defined private sector.
} 
However, not surprisingly, property rights protection remains weak, and the violation of property rights is prevalent, among the major problems that China faces. One of the major forms of property rights violation is the arbitrary levies imposed on private firms by local governments. Most of these arbitrary levies are not formal taxes. Instead, they are imposed by local governments arbitrarily, without justification by laws, and in complete absence of citizens' consent. From time to time, even the Chinese central government condemns these levies as "irrational," "extralegal," or even "illegal." According to a classic principle of property rights and taxation, charging levies without citizens' consent - for example, the approval of the citizens' representatives - or without legal support is a violation of property rights. "[T] he supreme power [i.e., the government] cannot take from any man any part of his property [e.g., collecting taxes] without his own consent. For the preservation of property being the end of government" (Locke [1689] 1823, p. 165). This principle is not only followed by generations of leading scholars, such as Smith ([1776] 1981) and North (1981), but is also the basis for constitutions of all democracies. When this rule is breached and governments violate property rights, entrepreneurs have to exert extra effort to deal with these institutional obstacles at a cost to their time and effort in management activities. The nature of these problems faced by Chinese entrepreneurs is similar to those discussed by Adam Smith when he stated that property rights institutions affect entrepreneurship. ${ }^{6}$

This study investigates the effects of institutional impediments on the allocation of time (effort) of entrepreneurs in modern China. We model an entrepreneur's time-effort allocation problem when subjected to a property rights protection constraint. Analytically, this model extends Becker's (1965) model by adding an institutional constraint. In our model, the time of an entrepreneur is allocated between leisure and work, which is further allocated between management and lobbying time for protecting property rights and dealing with related matters. We theoretically show that entrepreneurs devote more time to lobbying activities when property rights protection is weaker. Moreover, entrepreneurs' political connections may improve lobbying efficiency, such that the sensitivity of lobbying efforts to property rights protection is moderated.

The above-mentioned theoretical hypotheses are tested empirically. We find that property rights institutions significantly affect the time allocation

\footnotetext{
5 The Chinese economy relies heavily on subnational governments, including fiscal and financial aspects (Xu 2011). However, the central government takes most of the tax revenues from local governments, so that local governments have to find other sources of revenue. Thus, extralegal levies have become important revenue sources for local governments and have grown rapidly in the past 2 decades.

6 "Commerce and manufactures can seldom flourish long in any state which does not enjoy a regular administration of justice, in which the people do not feel themselves secure in the possession of their property, in which the faith of contracts is not supported by law, and in which the authority of the state is not supposed to be regularly employed in enforcing the payment of debts from all those who are able to pay" (Smith [1776] 1981, 910).
} 
of entrepreneurs at work. In particular, entrepreneurs of firms that are charged with higher levies, that is, are suffering more severe property rights violation, tend to allot more time to lobbying activities, thus costing time used for management activities. Moreover, the sensitivity of lobbying time to property rights protection is reduced if the entrepreneur is politically connected or if the firm is larger or older.

To identify the causal relationship between property rights protection and the time entrepreneurs devote to lobbying activities, we conduct twostage estimations with two instrumental variables (IVs) to address potential omitted-variable bias and endogeneity issues. The first IV refers to the weights of provincial-government policies on nonstate sectors. The second IV refers to the efforts of provincial-level governments in fighting corruption. We suggest that both IVs are good predictors of whether the local firms will be charged with higher levies or not, whereas neither IV should be related to error terms of the estimations of the individual time allocation of entrepreneurs. Moreover, we apply the overidentification strategy by using two IVs that allow us to statistically test the relevance and exogeneity of the IVs. The two-stage estimations confirm that our IVs are satisfactory and our empirical findings are robust.

The rest of this study is organized as follows. Section II describes the institutional background of private property rights protection and lobbying activities of entrepreneurs in China. Section III introduces the analytical framework. Section IV provides information on data and definitions of variables. Section V reports empirical findings. Section VI concludes the study.

\section{Property Rights Institutions and Lobbying Activities of Entrepreneurs}

During the prereform era in China, private ownership was completely illegal. The economic reform launched in 1978 did not have an agenda to allow for private ownership, as this contradicts socialist ideology. ${ }^{7}$ Throughout the reform and development process, lingering institutional and ideological biases against the private sector remained. The development of the private sector and privatization has been gradually tolerated since the 1990s, when the state sector became mired in deep trouble, whereas privately owned firms were still not granted de jure rights (Xu 2011). The de facto private sector took off rapidly after 1997, when de facto privatization was permitted officially. ${ }^{8}$ Since then, the private sector underwent significant

\footnotetext{
${ }^{7}$ Private enterprises were not formally permitted to exist until 1988, with the enactment of the Private Enterprise Administration Act, which was enacted 10 years after the start of the economic reform. However, even then, the constitution did not recognize private property rights.

8 The Partnership Enterprise Law and the Sole Proprietorship Enterprise Law were enacted in 1997 and 1999, respectively.
} 
development before the constitutional recognition of private ownership, which happened in 2004.

The share of the private sector in the total GDP increased from 2.5 percent in 1998 to nearly 50 percent in 2009. With its rapid growth rate, the private sector has become the largest engine of economic growth in China. By the end of 2011, the private sector comprised approximately 9.68 million registered private businesses and 37.56 million individually owned businesses. Moreover, more than 160 million jobs, or 90 percent of the new jobs in the nation, had been created by the private sector by the end of 2011 (Yearbook of China Private Economy 2012).

Nonetheless, the institutions under which the private sector operates remain far from favorable. The protection of property rights remains poor because of the weak law enforcement (Clarke, Murrell, and Whiting 2008). Anecdotes show that local governments may confiscate the wealth of private firms within their jurisdictions. Gong Jialong, former chairman of the Tianfa Group, which was the largest Chinese private oil company, was detained for alleged economic crimes in 2006. After one year and 7 months of trial, Gong was released and was found not guilty. However, his oil empire was swiftly broken up, and most of the businesses were sold to state-owned enterprises (SOEs) at a government auction during his absence. ${ }^{9}$ In other high-profile legal cases related to private businesses, entrepreneurs were not as fortunate as Gong; that is, they not only lost their assets but also were sentenced to long imprisonment or even death, for example, Lou Hengwei, Xu Ronghua, Zhu Menghe, Feng Yongming, and Yang Jinde. ${ }^{10}$

One of the most prevalent government expropriations is in the form of various nontax levies, charges, and fines applied to firms. These levies are arbitrary and are not based on formal rules or laws. Government revenues consist of three major types: budgetary revenue, extrabudgetary revenue (EBR), and nonbudgetary revenue (NBR; Wong 1997; Brown 1998). Of the three types, EBR and NBR are the main sources of local-government revenue. In 2006, EBR and NBR amounted to RMB 640.79 billion (3.02 percent of total GDP) and comprised 93.2 percent of the total local-government spending in that year (China National Statistical Yearbook 2008). Most EBR and NBR are collected in the forms of nontax levies.

Local governments have high discretionary power in imposing levies, fees, and other burdens, as these levies are not regulated by laws or legislators. Self-collection and self-utilization policies for EBR and NBR encourage local governments to collect nontax levies. Nationwide, approximately 7,600 types of nontax levies were documented before July 2007, among which only 30 had a precise legal basis, 400 were justified by certain regu-

\footnotetext{
9 "Former China Oil Tycoon Plots Return with Canadian Gas Venture" (Reuters, March 18, 2014; http:/ /www.reuters.com/article/china-tycoon-gas-idUSL3NOLV30N20140318).

10 "Private Enterprises Are Facing the Risk of Justice" (The Economic Observer, November 2, 2011; in Chinese).
} 
lations or policies, and 7,100 were imposed by local governments without legal justification. ${ }^{11}$ In taking Anhui Province as an example, 24,441 government agencies at different levels in the province charged 438 items of nontax levies that accounted for RMB 9.52 billion ( 34.7 percent of the local revenues) in 2004..$^{12}$ These nontax levies and charges arbitrarily imposed by various government departments are common ways of government expropriation, rent-seeking by corrupt officials, or both, and they lower the security of property rights (Lin, Lin, and Zou 2012).

Zong Qinghou, the chairman of the largest domestic beverage and food producer and the second-richest man in China, according to the Forbes "rich list," stressed that his Wahaha Group pays more than 400 different government administrative charges each year. ${ }^{13}$ According to the Nationwide Survey on Enterprise Burdens conducted by China Center for Promotion of SME Development (a government agency under the Ministry of Industry and Information Technology), the burden of the levies can be as high as 80 percent of the net profit. Concretely, by average, 4.1 percent of the total revenue of the enterprises was paid as nontax levies in $2012 .{ }^{14}$ As a comparison, the average tax was 7.8 percent, whereas the net profit of the firms was 5.1 percent of the total revenue..$^{15}$ Another survey, conducted by the National Development and Reform Commission of the State Council, shows that the illegal fees charged by banks accounted for 15 percent of the total costs of corporate bank loans in 2012. ${ }^{16}$

Facing high levy burdens at the discretion of the local governments, that is, the expropriation of property rights, entrepreneurs have to make substantial efforts to lobby local governments to protect their businesses. Feng Lun, chairman of Vantone Group, one of the largest private estate developers in China, reported that two-thirds of the 180 business trips he made in 2011 were lobbying related. ${ }^{17}$ In addition to becoming acquainted with and bribing government officials, successful entrepreneurs often are more creative than others in lobbying, in terms of whom to lobby, what to lobby, and how to lobby. Wang Jianlin, who was ranked as the richest entrepreneur in China in 2013 and 2014, asserted in his lecture at the Harvard Business School that "cultivating intimate relationships with the govern-

\footnotetext{
${ }^{11}$ For details, see "Act on Administrative Fees: Why Do We Have to Wait for So Long?" (Democracy and Rule of Law Weekly [minzhu yu fazhi zhoukan], November 14, 2007).

${ }^{12}$ For details, see http://politics.people.com.cn/GB/30178/4111634.html (in Chinese).

${ }^{13}$ For details, see "Wahaha Boss Urges Tax Cuts to Lift Growth" (South China Morning Post, August 25, 2014; http://news.ifeng.com/a/20170118/50596552_0.shtml (in Chinese).

${ }^{14}$ http://finance.ifeng.com/a/20161221/15092384_0.shtml (in Chinese).

15 The average ratio of the levies reported in the survey conducted in 2012 is significantly higher than that reported in the survey we used in this study, which was conducted in 2006. This finding is consistent with the anecdotes reported by mass media that the burdens from levies have been significantly increased in recent years.

${ }^{16}$ For details, see http://finance.people.com.cn/n/2013/0925/c1004-23025543.html (in Chinese).

${ }^{17}$ For details, see http://finance.ifeng.com/business/renwu/20130128/7610444.shtml (in Chinese).
} 
ment in China is more difficult than conducting a post-doc research at Harvard." 18

Finding ways to protect property rights is an essential task for entrepreneurs. Besides direct lobbying efforts, entrepreneurs may also cultivate political connections for protection. ${ }^{19}$ Indeed, more than one-third of the private firms in our sample are owned by veteran party members who were well connected to the government even before starting a private business. This study attempts to capture how entrepreneurs allocate their time to lobbying and management activities, depending on the institutional issues they face and the political connections they have.

\section{Analytical Framework}

Our analytical framework is based on Becker (1965) and inspired by North (1981), Acemoglu (1995), and Acemoglu and Johnson (2005). We study the allocation of time or efforts by entrepreneurs to maximize utility when property rights are not secure. The time of the entrepreneur is allocated between leisure and work, which is further divided between management and lobbying time to protect property rights and deal with related matters. We formally denote the utility function $U(y, \ell)$, where $y$ is income, and $\ell$ is leisure. The utility function satisfies the usual conditions; that is, $(\partial / \partial y) U=U_{1}>0,(\partial / \partial \ell) U=U_{2}>0, U_{11}<0, U_{22}<0$, and $U_{12}=U_{21}>0$. Total endowed time $T$ will be allocated between working time, $h$, and leisure time, $\ell$. That is, $\ell=T-h$. Total working time consists of management and lobbying time, that is $h=m+\rho$. The income, $y$, of the entrepreneur, as the largest owner of the firm, consists of a profit share of the firm and wealth. We denote the ownership share of the entrepreneur as $\alpha$ and wealth as $W$. We assume that the profit of the firm is a function of the entrepreneur's working hours, that is, $\xi m$, where $\xi$ is the marginal productivity of $m$. Thus, the budget constraint of the entrepreneur is $y=$ $\alpha \xi m+W$.

To capture the entrepreneur's loss due to insecure property rights, we assume that a fraction $\varphi$, where $\varphi \in[0,1]$, of the disposable income of the entrepreneur from the firm, $x(h, \rho)$, will be taken by the local government. This deduction may include local-government-imposed levies, other burdens, partial confiscations, and so on. We suppose that an entrepreneur can mitigate the loss by lobbying the local government. A simple way to

\footnotetext{
${ }^{18}$ For details, see http://money.163.com/12/0919/17/8BPITLLM00253G87_all.html (text; in Chinese) and http://www.wanda.cn/2013/chairman_0724/28.html (video; in Chinese).

${ }^{19}$ A stream of literature studies the different effects of entrepreneurs' political connections on the performance and accessibility to bank loans of the firms (Peng and Luo 2000; Fan, Wong, and Zhang 2007; Li et al. 2008; Francis, Hasan, and Sun 2009). In particular, Guo et al. (2014) find the 2004 constitutional amendment to be a turning point: politically connected entrepreneurs have obtained significantly more bank loans than other entrepreneurs since then.
} 
model this situation is that $(1-\rho) \varphi$ of the disposable income of the firm will be taken by the local government; that is, an entrepreneur's lobbying activity $\rho$ can reduce the loss. Thus, the institutional constraint is

$$
x(h, \rho)=[1-(1-\rho) \varphi] \xi(h-\rho) .
$$

The institutional constraint captures an entrepreneur's lobbying activities for reducing his levies, which is different from lobbying for changing taxation. First, levies, $\varphi$, are different from taxation because taxation is determined exogenously by the national government, and lobbying from individual entrepreneurs will not affect it. Second, in our model, the local authority has no right to set up or change taxation systems. Ownership share $\alpha$ can be interpreted partly as a tax to some extent, which is a fixed rule set up and enforced exogenously such that the entrepreneur is unable to influence the measure.

In this economy, the entrepreneur allocates total working time $h$ and lobbying time $\rho$ to maximize utility, subject to institutional constraint. That is,

$$
\max _{h, \rho} U(\alpha x(h, \rho)+W, T-h),
$$

subject to equation (1). Trade-offs between managing the firm and addressing institutional constraints affect the way the entrepreneur allocates total working time versus leisure and the amount of lobbying time $\rho$ that the entrepreneur will spend protecting property rights. From equation (1), we have the marginal productivity of working hour $h$,

$$
x_{h}=[1-(1-\rho) \varphi] \xi .
$$

It shows that when institutional cost $\varphi$ increases, marginal productivity of total working hours decreases. We also have the marginal productivity of lobbying time $\rho$,

$$
x_{\rho}=(\varphi+h \varphi-2 \varphi \rho-1) \xi .
$$

Substituting constraint condition (1) into the objective function, the firstorder condition of program (2) with respect to $h$ and $\rho$ is $\alpha U_{1} x_{h}=U_{2}=$ $\alpha U_{1} x_{\rho}$. Thus, at optimum,

$$
\frac{U_{2}}{U_{1}}=\alpha x_{h}=\alpha x_{\rho} .
$$

From equations (3)-(5) we have

$$
1-(1-\rho) \varphi=\varphi+h \varphi-2 \varphi \rho-1 .
$$

From equation (6), we can obtain $\partial \rho / \partial \varphi>0$, a comparative static result characterizing the equilibrium behavior of the entrepreneur. One of the major observable variables that measure violation of property rights is the arbitrary levy imposed by local governments on entrepreneurs. Em- 
pirically, we interpret $\varphi$ as the levy. Thus, we have the following empirical predictions.

Нyротнеsis 1. Everything else being equal, the heavier the levy $\varphi$ imposed on the entrepreneur, the more lobbying time $\rho$ (or the less management time $h-\rho$ ) spent by the entrepreneur.

In addition to spending time in lobbying activities, political connections may also be important in providing protection to entrepreneurs by improving lobbying efficiency. In our highly stylized simple model, this is captured by political connections or lobbying efficiency, $z$, in the institution constraint as follows:

$$
x(h, \rho)=[1-(1-z \rho) \varphi] \xi(h-\rho),
$$

where $z>1$ for politically connected entrepreneurs and $z=1$ otherwise. Thus, lobbying time $\rho$ increases when $\varphi$ increases, but increases less for politically connected entrepreneurs than for others because they have higher productivity, $z$, in their lobbying activities.

Hypothesis 2. Everything else being equal, the heavier the levy, $\varphi$, the more lobbying time $\rho$ (or less management time $h-\rho$ ) an entrepreneur will spend. Moreover, for politically connected entrepreneurs $\rho$ will increase less (or management time $h-\rho$ will decrease less) than for other entrepreneurs.

\section{Data and Variables}

Data used in this study are obtained from the Survey of China's Private Enterprises. This survey was conducted in 2006 via a stratified randomsample survey approach. To ensure representativeness of the data, the population of private firms was stratified by location (i.e., provinces, cities/ counties), stage of economic development, urban and rural locations, and industry. The sample size of the survey is 3,837 . The firms surveyed are located in 109 cities, equivalent to roughly one-third of Chinese cities.

Survey data were collected via face-to-face interviews. The survey provides a broad range of information on the governance of entrepreneurial firms; interactions among private business activities and institutions, such as local governments, local courts, and regulations; and other factors. Entrepreneurs were asked to report on the ways they allocate time and on other subjects, for example, finance and governance of their firms. The survey collected sociodemographic characteristics of the entrepreneurs.

The survey's sampling scheme was carefully designed for representativeness. However, data collection was organized by or with the assistance of the government. ${ }^{20}$ Thus, the sample may have potential bias in that, com-

\footnotetext{
20 The survey was designed by sociologists and organized by the United Front Work Department of the Communist Part of China Central Committee, the National Association of Industry and Commerce, the State Administration for Industry and Commerce, and the Private Economy Academy of China.
} 
pared with all firms in the population, the sampled entrepreneurs may be closer to the government. Consequently, the actual problem in the overall population might be more severe than what we uncovered from the survey sample.

Time allocation of entrepreneurs is the major type of variable in this study. The survey asked entrepreneurs for detailed information on the amount of time they devoted to different activities per day, including work and leisure. When entrepreneurs were asked to report their normal working hours, they were asked to specify the time they devoted to management activities, networking activities, ${ }^{21}$ and learning per day. That is, the total working time consists of three components. We sum these three components and build a variable for total working hours. The variable "Work time" is the total number of hours the entrepreneur devotes to management, networking, and learning activities per day, which distinguishes the time allocation of the entrepreneur between work and leisure. Our major interests are the ratio of time spent in lobbying activities over total working time, "Lobby_Rt," and the ratio of time allotted to management activities over total working time, "Mng_Rt." Table 1 shows that the sampled entrepreneurs work for 12.48 hours per day, on average. On average, respondents spend 3.26 hours, that is, more than 26 percent of their working time, on lobbying activities; 7.5 hours, that is, about 60 percent of their working time, on management; and 1.40 hours on study during their working hours. It is worth noting that, on average, the time allocated to lobbying and management activities accounts for over 86 percent of the total working hours of entrepreneurs. The figure suggests that the increase in lobbying efforts normally may come at a cost to the management efforts of the entrepreneurs. Therefore, in many cases, we should expect Mng_Rt and Lobby_Rt to be mirror images. Indeed, our model predicts that the violation of property rights drives entrepreneurs to exert more effort toward lobby activities, at a cost to managing the business. We therefore maintain the mirror image of the two variables in all estimations to highlight the considerable significance of the costs.

In terms of institutional impediments, we focus on the violation of property rights. As mentioned above, local governments impose various levies on entrepreneurs. In the survey, entrepreneurs were asked to report the total amount of all levies paid to the government beyond tax in the previous year. We use this information to construct our measurement for property rights violation. We first calculate the ratio of fees over sales for each firm ("Forced_fee"). On the basis of this ratio, we construct the variable "High_fee," a dummy variable that is equal to one if the firm is in the highest 25 percent of Forced_fee and zero otherwise. Table 1 shows that on average, firms pay 0.6 percent of their total sales to local governments as

\footnotetext{
${ }^{21}$ As the survey was conducted by official agencies, the term "networking" is used. However, most "networking" in China's context is about building connections with the government for lobbying purposes.
} 
TABLE 1

Summary Statistics

\begin{tabular}{lrrrrr}
\hline & & & Standard \\
Variable & Observations & Mean & Deviation & Minimum & Maximum \\
\hline Work_time (hours) & 3,413 & 12.484 & 2.614 & 6.000 & 18.000 \\
Lobby_hour (hours) & 3,570 & 3.258 & 1.825 & 0 & 10.000 \\
Mng_hour (hours) & 3,696 & 7.507 & 2.552 & 2.000 & 14.000 \\
Lobby_Rt & 3,412 & .264 & .135 & 0 & .667 \\
Mng_Rt & 3,412 & .596 & .152 & .200 & .909 \\
Study_Rt & 3,412 & .140 & .076 & 0 & .750 \\
Forced_fee/sales & 1,982 & .006 & .017 & 0 & .115 \\
High_fee & 1,982 & .250 & .433 & 0 & 1.000 \\
CPC & 3,446 & .405 & .491 & 0 & 1.000 \\
CEO_share (\%) & 3,242 & 67.996 & 26.943 & 0 & 100.000 \\
CEO_income (RMB 10,000) & 3,404 & 23.976 & 41.439 & 1.000 & 300.000 \\
CEO_age (years) & 3,808 & 44.381 & 8.150 & 26.000 & 65.000 \\
CEO_edu & 3,815 & .859 & .348 & 0 & 1.000 \\
Privatization & 3,600 & .203 & .402 & 0 & 1.000 \\
Firm_age (years) & 3,690 & 7.052 & 4.443 & 1.000 & 20.000 \\
Firm_size (log no. of employees) & 3,572 & 3.854 & 1.550 & .693 & 7.824 \\
Anti-Corruption & 3,837 & .282 & .069 & .151 & .492 \\
CVRG & 3,772 & 59.453 & 30.921 & 2 & 132 \\
\hline
\end{tabular}

additional fees. However, this ratio has a highly skewed distribution. Certain firms pay considerably more than others, such that the median is less than the average, the standard deviation is larger than the mean, and the maximum Forced_fee is 11.5 percent.

To prevent our estimations from being driven by omitted variables, we control for entrepreneur and firm characteristics as well as for region and industry effects. Regional effects are measured by a dummy variable that is equal to one if the province is defined as an "economically developed province" by the Chinese National Statistical Bureau in 2006 and zero otherwise. Industry effect is captured by industry dummy variables that identify the industries of the firm. Detailed definitions of the variables are in table A1. Variables related to entrepreneurial characteristics include age ("CEO_age"), gender ("CEO_gender"), education ("CEO_edu"), and disposable income ("CEO_income") of the entrepreneur gained from the firm. Table 1 shows that, on average, 68 percent of the assets of the firm are owned by entrepreneurs. The average income of the entrepreneur, including salaries and dividends gained in the previous year, is about RMB 240,000 (with a large standard deviation of RMB 414,390). Moreover, the average age of the entrepreneur is 44 years, and 85.9 percent have high school or higher education.

Variables related to firm characteristics include size ("Firm_size") and age ("Firm_age") of the firm, and whether the firm was privatized from a former SOE ("Privatization"). Table 1 shows that the average firm age is 7 years and the average firm size is 52 employees. Approximately 20 percent of the firms in the sample are privatized.

We are also interested to see how political connections affect lobbying efficiency (hypothesis 2), that is, how connections moderate the sensitiv- 
ity of the lobbying efforts to property rights violation. We measure entrepreneurs' political connections by their party membership with a dummy variable, "CPC," that it is equal to one if the entrepreneur is a Communist Party of China (CPC) member at the time of the survey and zero otherwise. Approximately 41 percent of the firms in our sample are owned by CPC members. Moreover, nearly 80 percent of these CPC member entrepreneurs are veteran party members who joined the party and cultivated political connections with the government long before establishing a private business.

Table 2 presents the comparison of all the variables of our interest between the group of firms that are charged high fees and those that are not charged high fees, along with the $t$-tests. On average, firms being charged high fees pay 2.3 percent of their total sales as levies, while the ratio for the counterpart firms is 0.06 percent, and this difference is statistically significant. Moreover, these two groups are significantly different in other aspects. In particular, on average, entrepreneurs of firms that are charged high fees allocate more time to working activities and then spend a higher proportion of their working time on lobbying activities and a lower proportion of working time to management activities than the others. Moreover, bigger firms and privatized former SOEs are less likely to have high fees imposed on them than the others. Furthermore, entrepreneurs of the high-fee firms are more likely to be younger and less likely to be politically connected.

\section{Empirical Findings}

\section{A. Property Rights Institution and Time Allocation}

To investigate the impact of property rights protection on time allocation of entrepreneurs systematically, we estimate the following equation:

$$
\text { Time_ratio }_{i}=\alpha+\beta \text { High_fee }_{i}+d X_{i}+\varepsilon_{i},
$$

where Time_ratio ${ }_{i}$ measures the proportion of time spent by entrepreneur $i$ for various activities, including Lobby_Rt, the lobbying time/total working time ratio; Mng_Rt, the management time/total working time ratio; and Work_time, the total working hours spent by the entrepreneur. Here, High_fee ${ }_{i}$ is a dummy variable that is equal to one if the levy/sales ratio for firm $i$ in the previous year (i.e., 2005) is in the top 25 percent and zero otherwise. The term $X_{i}$ is a vector of control variables for firm $i$ and includes characteristics of both the entrepreneur and the firm.

Table 3 presents our baseline regression estimations. Column 1 reports (in the first row) the effects of charging high fees (i.e., High_fee $=1$ ) to entrepreneurs on their choice of total working hours. No statistically significant relationship is observed between High_fee and total working hours. Hence, property rights protection may not affect the time allocation between work and leisure in general. However, column 2 shows that High_fee 


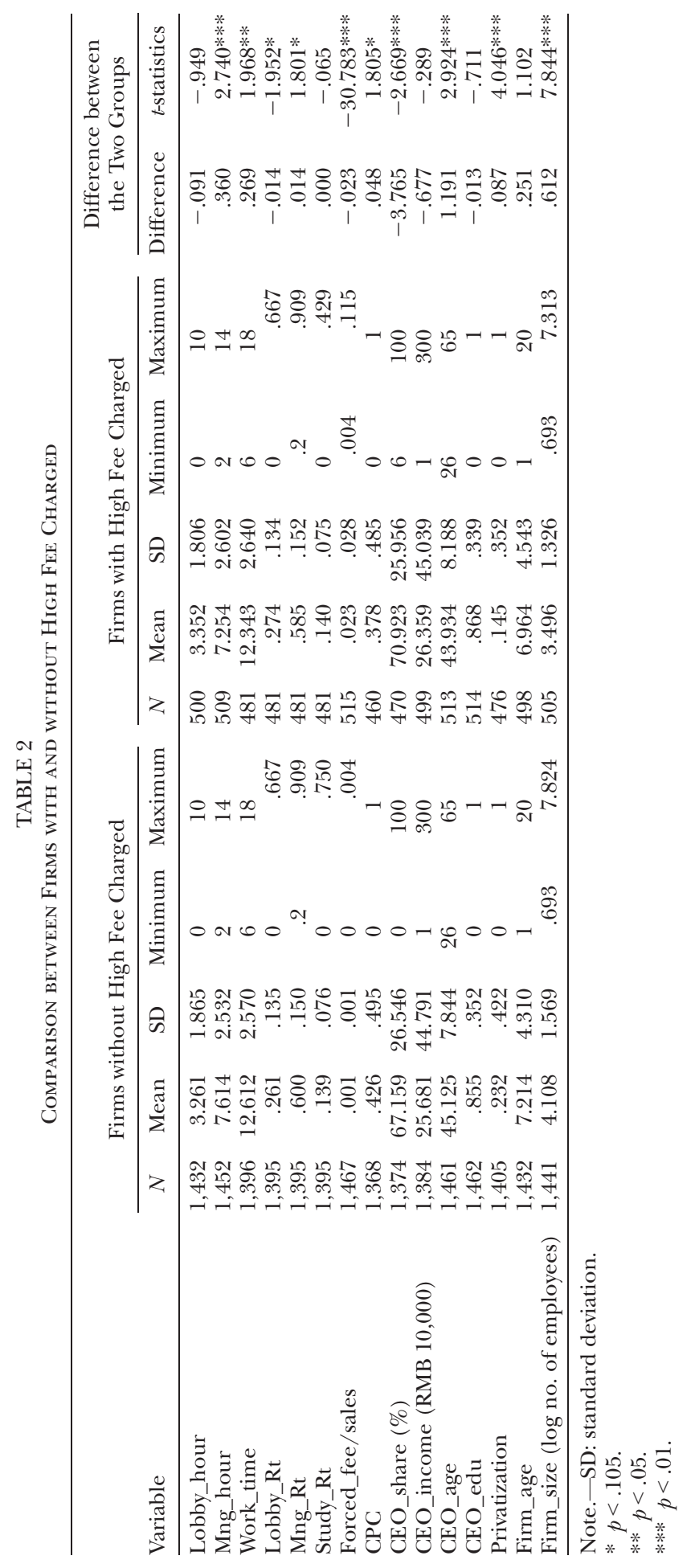


TABLE 3

Property Rights Violation and Time Allocation

\begin{tabular}{lccccc}
\hline & Work_time & Lobby_Rt & Mng_Rt & Lobby_hour & Mng_hour \\
& $(1)$ & $(2)$ & $(3)$ & $(4)$ & $(5)$ \\
\hline High_fee & -.173 & $.019^{* *}$ & $-.022^{* *}$ & .186 & $-.497^{* * *}$ \\
& $(.169)$ & $(.009)$ & $(.010)$ & $(.121)$ & $(.164)$ \\
CEO_share & .004 & $-8.48 \mathrm{E}-5$ & $3.06 \mathrm{E}-4^{* *}$ & $4.60 \mathrm{E}-4$ & $.005^{* *}$ \\
& $(.003)$ & $(1.42 \mathrm{E}-4)$ & $(1.56 \mathrm{E}-4)$ & $(.002)$ & $(.003)$ \\
CEO_income & $-.004^{* *}$ & $3.08 \mathrm{E}-4^{* * * *}$ & $-4.19 \mathrm{E}-4^{* * *}$ & $.003^{* * *}$ & $-.008^{* * *}$ \\
& $(.002)$ & $(8.36 \mathrm{E}-5)$ & $(9.16 \mathrm{E}-5)$ & $(.001)$ & $(.002)$ \\
CEO_age & $.016^{*}$ & $-.001^{* *}$ & $.001^{* *}$ & -.008 & $.027^{* * *}$ \\
& $(.010)$ & $(4.99 \mathrm{E}-4)$ & $(.001)$ & $(.007)$ & $(.009)$ \\
CEO_gender & -.276 & $-.030^{* * *}$ & $.030^{* *}$ & $-.448^{* * *}$ & .212 \\
& $(.217)$ & $(.011)$ & $(.012)$ & $(.156)$ & $(.212)$ \\
Firm_age & .026 & $3.37 \mathrm{E}-4$ & $3.94 \mathrm{E}-4$ & .012 & .018 \\
& $(.017)$ & $(.001)$ & $(.001)$ & $(.013)$ & $(.017)$ \\
CEO_edu & .298 & .006 & -.015 & .038 & .052 \\
& $(.207)$ & $(.011)$ & $(.012)$ & $(.149)$ & $(.201)$ \\
Privatization & .194 & -.007 & $3.33 \mathrm{E}-4$ & .059 & .011 \\
& $(.183)$ & $(.010)$ & .011 & $(.133)$ & $(.180)$ \\
Firm_size & $.136^{* *}$ & $.007 * *$ & $-.009 * * *$ & $.131^{* * *}$ & -.019 \\
& $(.056)$ & $(.003)$ & $(.003)$ & $(.041)$ & $(.055)$ \\
Constant & $10.84^{* * *}$ & $.303^{* * *}$ & $.545^{* * *}$ & $3.305^{* * *}$ & $5.853^{* * *}$ \\
& $(.610)$ & $(.032)$ & $(.035)$ & $(.441)$ & $(.600)$ \\
Industry effect & $\mathrm{Y}$ & $\mathrm{Y}$ & $\mathrm{Y}$ & $\mathrm{Y}$ & $\mathrm{Y}$ \\
Regional effect & $\mathrm{Y}$ & $\mathrm{Y}$ & $\mathrm{Y}$ & $\mathrm{Y}$ & $\mathrm{Y}$ \\
Observations & 1,439 & 1,439 & 1,439 & 1,473 & 1,488 \\
Pseudo- $R^{2}$ & .009 & -.057 & -.083 & .011 & .012 \\
$p$-value & .001 & .000 & .000 & .000 & .000 \\
\hline
\end{tabular}

Note.-Standard errors in parentheses.

$* p<.105$.

$* * p<.05$.

$* * * \quad p<.01$.

is positively and significantly correlated with Lobby_Rt. On average, entrepreneurs who have to pay higher levies normally allocate about 1.9 percent (about 7 percent of the mean) more time to lobbying activities than those paying lower levies. Column 3 illustrates that Mng_Rt is negatively and significantly correlated with High_fee, indicating that higher levies significantly reduce the time allocated to managing business. On average, entrepreneurs who have to pay higher levies normally allot about 2.2 percent (about 4 percent of the mean) less time to management activities. These results indicate that, everything else being equal, entrepreneurs facing more severe violation of property rights spend significantly more time on lobbying activities, at a cost to management time. This result is consistent with the prediction of hypothesis 1 of our model.

To cross-check the results of our estimations, we include the absolute amount of lobbying and management time allotted by entrepreneurs, as seen in columns 4 and 5 , respectively, of table 3 . The variable High_fee is significantly and negatively associated with the number of hours allotted to management time, implying that entrepreneurs who need to pay higher levies normally reduce time for management activities. Moreover, 
although not statistically significantly, High_fee and the number of hours spent lobbying activities are positively correlated.

Table 3 further reveals interesting findings on the relationship between time allocation and characteristics of the firm and the entrepreneur. First, in general, entrepreneurs receiving higher compensation spend less time on work but allot a larger part of their work time to lobbying activities than others. Second, we observe that entrepreneurs of larger-sized firms allot more time to work than those of smaller firms in general and spend a higher proportion of work time on lobbying activities and a lower proportion of work time on management activities. A potential explanation for these findings is that entrepreneurs who have more wealth choose to allot more time to leisure than work. Given the weak property rights protection, the marginal benefits of lobbying efforts may be higher for those who have greater wealth and larger firms than for entrepreneurs with lesser wealth and smaller firms.

Moreover, as minor points of this paper, we observe that older entrepreneurs tend to allot more time to work and allocate a higher ratio of their work time to management activities than younger entrepreneurs. This may reflect a change in the lifestyle of different generations in terms of work and leisure choice. Finally, although no statistically significant difference is reported between female and male entrepreneurs in terms of their allocation of time between work and leisure, we observe that female entrepreneurs allocated more time to management and less time to lobbying activities than male entrepreneurs.

To test the robustness of our definition of High_fee, we attempted different cutoffs around 25 percent (i.e., 20, 23, 28, 30, 33, and 35 percent). The results of our estimations basically remained robust (results are provided by request).

\section{B. Identification Strategies}

In the previous subsection, we report that violation of property rights is associated with an increase in lobbying time and a decrease in management time. Yet there are alternative competing interpretations to the observed correlation. Hence, we discuss identification strategies in this subsection, including concerns on issues such as reverse causality and omitted variables.

First, in principle, we are not too concerned with reverse-causality issues because of the nature of the survey data. All financial information, including imposed fees, reported in the survey is based on the information for the previous financial year, whereas time allocation information is based on the average in the recent few months. Hence, the gap in timing for the information of the two variables implies that the levies and fees imposed on the firms cannot be results of time allocation.

However, identification concerns related to omitted variables may remain. Although we have controlled a set of variables to control character- 
istics of entrepreneurs and firms and region and industry effects, certain unobservable factors that potentially affect time allocation may still be omitted. For instance, the family background or social values of the entrepreneur may be coincidentally correlated to additional levies imposed on the entrepreneurial firm. Thus, it is plausible that the significant relationship we observed between the variable High_fee and time allocation might be driven by unobservable factors rather than by property rights violation.

To address the potential identification concerns, we use 2-stage least squares (2SLS) estimation to identify the effects of violation of property rights. In particular, we use two IVs to identify whether the firm is more likely to be charged with high fees. By using two IVs, we can test the relevancies between the IVs and our major explanatory variable and also test the exogeneity of the IVs from the error terms of our estimations affecting the dependent variables.

Our first IV is the weight of provincial-government policies on nonstate sectors, measured by the frequency of the keyword "nonpublic-sector development" in articles written by party chiefs of provincial party committees in the 2 years before the survey, denoted "CVRG." The data are covered by the Database of Chinese Communist Party Construction Periodicals (Zhonggong Dangjian Qikan Shujuku), which is the largest database of digitized CPC periodicals. The database covers 215 major CPC periodicals starting from 1994. Most periodicals in the database are published by party committees at the provincial and municipality levels. ${ }^{22}$ The subnational-level party periodicals are the major platform through which provincial and municipal party committees promote policies within their jurisdictions. This IV satisfies the two conditions of exogeneity and relevance. First, the frequency of the keywords "nonpublic-sector development" used by the party chief implies the extent to which the provincial-level CPC committee prioritizes and supports the development of the private sector, which is usually the largest component in the officially so-called nonpublic sector. Thus, we expect that in provinces where provincial party chiefs place significant emphasis on the nonpublic sector, property rights are better protected in general and entrepreneurs are less likely be charged high fees. However, the frequency of the phrase "nonpublic-sector development" used by the CPC chief of the province should not be related to error terms related to the time allocation of individual entrepreneurs.

The second IV is Anti-Corruption, which refers to the number of registered cases under the direct investigation of provincial procuratorates, divided by the provincial population (cases per 100,000 persons). We collect data for cases 2 years before the survey was conducted. Data are obtained from the Procuratorial Yearbook of China (2004 and 2005). The number of corruption cases under provincial procuratorate's investigation is a good indicator of the seriousness of a province in fighting corruption in

\footnotetext{
${ }^{22}$ It also covers several dozen national-level CPC periodicals published by the CPC central agencies, such as Qiushi, Dangiian, and Hongqi.
} 
the 2 years before the survey. Assuming that the indicator Anti-Corruption proxies for the provincial governments' anticorruption efforts (Cole, Elliott, and Zhang 2009), we expect that provinces fighting corruption more seriously protect property rights and that entrepreneurs are less likely to be charged high fees. Yet provincial-level anticorruption efforts should not be related to error terms that affect time allocation of the individual entrepreneurs.

Table 4 reports the 2SLS regression results when High_fee is applied in the two IVs. Panel A of table 4 presents the results from first-stage estimations. It suggests that the two IVs are satisfactory instruments. First, both CVRG and Anti-Corruption are significantly and negatively correlated with the dummy variable High_fee, confirming the relevance of the two IVs we used. The results of the Sargan tests indicate that both IVs are exogenous from unobserved factors that may affect individual time allocation. The results of the second-stage estimation are presented in panel B of table 4 . It shows that the instrumented High_fee is positively and significantly related to Lobby_Rt and negatively and significantly related to Mng_Rt.

Supported by the evidence presented in tables 3 and 4, we claim that hypothesis 1 cannot be rejected. That is, violation of property rights reduces entrepreneurs' management time. Moreover, the weaker the protection of property rights, the more likely it is that the entrepreneur devotes more time to lobbying activities, at a cost to management efforts.

\section{Political Connections and Time Allocation}

Hypothesis 2 of our model predicts that politically connected entrepreneurs are more efficient than others in using their lobbying time. Thus, they save more of their time for management. Approximately 40 percent of the firms in our sample are owned by CPC members. Moreover, nearly 80 percent of these CPC member entrepreneurs are veteran party members, meaning that they joined the party and cultivated political connections with the government long before starting a private business. Therefore, CPC membership is a good proxy for political connection and exogenous to time allocation. This condition allows us to explore the effects of political connections on time allocation. For this purpose, we specify the regression models as

$$
\begin{aligned}
& \text { Time_ratio }_{i}=\alpha+\beta \text { High_fee }_{i}+\theta \text { CPC }_{i} \\
& +\mu\left(\mathrm{CPC}_{i} \times \text { High_fee }{ }_{i}\right)+d X_{i}+\varepsilon_{i},
\end{aligned}
$$

where $\mathrm{CPC}_{i}$ is the measurement of political connection, that is, $\mathrm{CPC}$ membership of entrepreneur $i$. Our major interest is the interaction term between CPC and High_fee, that is, CPC $\times$ High_fee.

Table 5 presents the estimation results, which indicate the absence of a statistically significant relationship between CPC and any time allocation variables. Yet the interaction term CPC $\times$ High_fee is significantly and 
TABLE 4

Two-stage Estimations on Property Rights Violation and Time Allocation

\begin{tabular}{|c|c|c|c|c|c|}
\hline & $\begin{array}{l}\text { High_fee } \\
\text { (1) }\end{array}$ & $\begin{array}{c}\text { High_fee } \\
\text { (2) }\end{array}$ & $\begin{array}{c}\text { High_fee } \\
\text { (3) }\end{array}$ & $\begin{array}{l}\text { High_fee } \\
\text { (4) }\end{array}$ & $\underset{(5)}{\operatorname{High\_ fee}}$ \\
\hline & \multicolumn{5}{|c|}{ A. First Stage } \\
\hline Anti-Corruption & $\begin{array}{c}-2.161^{*} \\
(1.158)\end{array}$ & $\begin{array}{c}-2.161 * \\
(1.158)\end{array}$ & $\begin{array}{c}-2.161 * \\
(1.158)\end{array}$ & $\begin{array}{c}-2.198^{*} \\
(1.137)\end{array}$ & $\begin{array}{l}-2.269 * * \\
(1.122)\end{array}$ \\
\hline CVRG & $\begin{array}{c}-.007 * * \\
(.003)\end{array}$ & $\begin{array}{c}-.007 * * \\
(.003)\end{array}$ & $\begin{array}{c}-.007 * * \\
(.003)\end{array}$ & $\begin{array}{c}-.006^{* *} \\
(.003)\end{array}$ & $\begin{array}{c}-.006^{* * *} \\
(.003)\end{array}$ \\
\hline All control variables & $\mathrm{Y}$ & $\mathrm{Y}$ & $\mathrm{Y}$ & $\mathrm{Y}$ & $\mathrm{Y}$ \\
\hline$p$-value & .000 & .000 & .000 & .000 & .000 \\
\hline \multirow{2}{*}{\multicolumn{6}{|c|}{$\begin{array}{l}\text { Anderson canonical } \\
\text { correction LM statistics }\end{array}$}} \\
\hline & .063 & .063 & .063 & .065 & .049 \\
\hline Sargan statistics & .014 & .190 & .276 & .108 & 428 \\
\hline \multirow[t]{3}{*}{ Observations } & 1,430 & 1,430 & 1,430 & 1,464 & 1,479 \\
\hline & \multicolumn{5}{|c|}{ B. Second Stage } \\
\hline & $\begin{array}{l}\text { Work_time } \\
\quad(1)\end{array}$ & $\begin{array}{c}\text { Lobby_Rt } \\
(2)\end{array}$ & $\underset{(3)}{\text { Mng_Rt }}$ & $\begin{array}{c}\text { Lobby_hour } \\
\text { (4) }\end{array}$ & $\underset{(5)}{\operatorname{Mng} \text { hour }}$ \\
\hline \multirow[t]{2}{*}{ High_fee } & .650 & $.303 *$ & $-.348 *$ & $4.173^{*}$ & -4.186 \\
\hline & (2.607) & $(.182)$ & $(.204)$ & (2.559) & (2.867) \\
\hline \multirow[t]{2}{*}{ CEO_share } & .004 & $-2.58 \mathrm{E}-4$ & $.001 * *$ & -.002 & $.008^{* * *}$ \\
\hline & $(.003)$ & $(2.19 \mathrm{E}-4)$ & $(2.45 \mathrm{E}-4)$ & $(.003)$ & $(.004)$ \\
\hline \multirow[t]{2}{*}{ CEO_income } & $-.004^{*}$ & $1.71 \mathrm{E}-4$ & $-2.63 \mathrm{E}-4$ & .001 & $-.005 * *$ \\
\hline & $(.002)$ & $(1.45 \mathrm{E}-4)$ & $(1.63 \mathrm{E}-4)$ & $(.002)$ & $(.002)$ \\
\hline \multirow[t]{2}{*}{ CEO_age } & $.017 *$ & -.001 & .001 & -.003 & $.021 *$ \\
\hline & $(.010)$ & $(.001)$ & $(.001)$ & $(.010)$ & $(.011)$ \\
\hline \multirow[t]{2}{*}{ CEO_gender } & -.215 & -.020 & .018 & -.312 & .083 \\
\hline & $(.227)$ & $(.020)$ & $(.018)$ & $(.220)$ & $(.258)$ \\
\hline \multirow[t]{2}{*}{ Firm_age } & .022 & $1.74 \mathrm{E}-5$ & .001 & .004 & .024 \\
\hline & $(.017)$ & $(.001)$ & $(.001)$ & $(.017)$ & $(.020)$ \\
\hline \multirow[t]{2}{*}{ CEO_edu } & .310 & .004 & -.012 & .029 & .043 \\
\hline & $(.205)$ & $(.014)$ & $(.016)$ & (.196) & $(.228)$ \\
\hline \multirow[t]{2}{*}{ Privatization } & .212 & .008 & -.016 & .247 & -.181 \\
\hline & $(.222)$ & $(.016)$ & $(.017)$ & $(.216)$ & $(.261)$ \\
\hline \multirow[t]{2}{*}{ Firm_size } & .173 & $.020 * *$ & $-.024 * *$ & $.306^{* *}$ & -.179 \\
\hline & $(.135)$ & $(.010)$ & $(.011)$ & $(.128)$ & $(.145)$ \\
\hline \multirow[t]{2}{*}{ Constant } & $10.44 * * *$ & $.175^{*}$ & $.691 * * *$ & 1.598 & $7.487 * * *$ \\
\hline & $(1.284)$ & $(.090)$ & $(.101)$ & (1.219) & (1.386) \\
\hline Industry effect & Y & $\mathrm{Y}$ & $\mathrm{Y}$ & $\mathrm{Y}$ & $\mathrm{Y}$ \\
\hline Regional effect & Y & Y & Y & $\mathrm{Y}$ & Y \\
\hline Observations & 1,430 & 1,430 & 1,430 & 1,464 & 1,479 \\
\hline Prob $>F$ & .0017 & .0204 & .003 & .0692 & .001 \\
\hline
\end{tabular}

Note.-Standard errors in parentheses. LM: Lagrange multiplier.

$* p<.105$.

$* * x<.05$.

$* * * \quad p<.01$.

negatively correlated with Lobby_Rt and significantly and positively correlated with Mng_Rt. These results suggest that, everything else being equal, politically connected entrepreneurs spend relatively less time lobbying to deal with property rights violation than other entrepreneurs do. As a result, politically connected entrepreneurs save more time in management than others when others have to spend more time dealing with property rights violation. On average, politically connected entrepreneurs charged 
TABLE 5

Property Rights Violation, Political Connection, and Time Allocation

\begin{tabular}{|c|c|c|c|c|c|}
\hline & $\begin{array}{c}\text { Work_time } \\
\text { (1) }\end{array}$ & $\begin{array}{l}\text { Lobby_Rt } \\
\text { (2) }\end{array}$ & $\underset{(3)}{\operatorname{Mng} R t}$ & $\begin{array}{l}\text { Lobby_hour } \\
(4)\end{array}$ & $\underset{(5)}{\operatorname{Mng} \text { hour }}$ \\
\hline High_fee & $\begin{array}{r}-.285 \\
(.221)\end{array}$ & $\begin{array}{l}.031 * * * \\
(.012)\end{array}$ & $\begin{array}{l}-.040 * * * \\
(.013)\end{array}$ & $\begin{array}{l}.322 * * \\
(.157)\end{array}$ & $\begin{array}{c}-.848 * * * \\
(.214)\end{array}$ \\
\hline $\mathrm{CPC}$ & $\begin{array}{c}-.169 \\
(.177)\end{array}$ & $\begin{array}{l}.001 \\
(.009)\end{array}$ & $\begin{array}{c}-.001 \\
(.010)\end{array}$ & $\begin{array}{c}-.020 \\
(.127)\end{array}$ & $\begin{array}{c}-.137 \\
(.173)\end{array}$ \\
\hline $\mathrm{CPC} \times$ High_fee & $\begin{array}{l}.220 \\
(.357)\end{array}$ & $\begin{array}{c}-.030 * \\
(.018)\end{array}$ & $\begin{array}{l}.044^{* * *} \\
(.020)\end{array}$ & $\begin{array}{l}-.358 \\
(.255)\end{array}$ & $\begin{array}{l}.828 * * \\
(.345)\end{array}$ \\
\hline CEO_share & $\begin{array}{l}.004 \\
(.003)\end{array}$ & $\begin{array}{c}-5.94 \mathrm{E}-5 \\
(1.47 \mathrm{E}-4)\end{array}$ & $\begin{array}{c}2.67 \mathrm{E}-4 * \\
(1.60 \mathrm{E}-4)\end{array}$ & $\begin{array}{l}.001 \\
(.002)\end{array}$ & $\begin{array}{l}.005^{*} \\
(.003)\end{array}$ \\
\hline CEO_income & $\begin{array}{l}-.004^{* * *} \\
(.002)\end{array}$ & $\begin{array}{l}2.92 \mathrm{E}-4 * * * \\
(8.52 \mathrm{E}-5)\end{array}$ & $\begin{array}{c}-4.14 \mathrm{E}-4 * * * \\
(9.32 \mathrm{E}-5)\end{array}$ & $\begin{array}{l}.002 * * \\
(.001)\end{array}$ & $\begin{array}{l}-.007 * * * \\
(.002)\end{array}$ \\
\hline CEO_age & $\begin{array}{l}.017 * \\
(.010)\end{array}$ & $\begin{array}{c}-.001 * \\
(.001)\end{array}$ & $\begin{array}{l}.001 * * \\
(.001)\end{array}$ & $\begin{array}{c}-.007 \\
(.007)\end{array}$ & $\begin{array}{l}.027 * * * \\
(.010)\end{array}$ \\
\hline CEO_gender & $\begin{array}{r}-.228 \\
(.226)\end{array}$ & $\begin{array}{l}-.031 * * * \\
(.012)\end{array}$ & $\begin{array}{l}.033^{* * * *} \\
(.013)\end{array}$ & $\begin{array}{l}-.432 * * * \\
(.162)\end{array}$ & $\begin{array}{l}.290 \\
(.219)\end{array}$ \\
\hline Firm_age & $\begin{array}{l}.025 \\
(.018)\end{array}$ & $\begin{array}{c}.001 \\
(.001)\end{array}$ & $\begin{array}{c}-3.62 \mathrm{E}-4 \\
(.001)\end{array}$ & $\begin{array}{l}.022 * \\
(.013)\end{array}$ & $\begin{array}{l}.008 \\
(.018)\end{array}$ \\
\hline CEO_edu & $\begin{array}{l}.350 \\
(.219)\end{array}$ & $\begin{array}{l}.014 \\
(.011)\end{array}$ & $\begin{array}{l}-.025^{* *} \\
(.012)\end{array}$ & $\begin{array}{l}.145 \\
(.156)\end{array}$ & $\begin{array}{r}-.052 \\
(.211)\end{array}$ \\
\hline Privatization & $\begin{array}{l}.251 \\
(.193)\end{array}$ & $\begin{array}{r}-.005 \\
(.010)\end{array}$ & $\begin{array}{r}-.001 \\
(.011)\end{array}$ & $\begin{array}{l}.096 \\
(.139)\end{array}$ & $\begin{array}{l}.046 \\
(.189)\end{array}$ \\
\hline Firm_size & $\begin{array}{l}.133 * * \\
(.058)\end{array}$ & $\begin{array}{l}.006^{*} \\
(.003)\end{array}$ & $\begin{array}{l}-.007^{* * *} \\
(.003)\end{array}$ & $\begin{array}{l}.113 * * * \\
(.042)\end{array}$ & $\begin{array}{r}-.002 \\
(.056)\end{array}$ \\
\hline Constant & $\begin{array}{c}10.950 * * * \\
(.633)\end{array}$ & $\begin{array}{l}.298 * * * \\
(.033)\end{array}$ & $\begin{array}{l}.550 * * * \\
(.036)\end{array}$ & $\begin{array}{l}3.265 * * * \\
(.454)\end{array}$ & $\begin{array}{l}5.992 * * * \\
(.617)\end{array}$ \\
\hline Industry effect & $\mathrm{Y}$ & $\mathrm{Y}$ & $\mathrm{Y}$ & $\mathrm{Y}$ & $\mathrm{Y}$ \\
\hline Regional effect & $\mathrm{Y}$ & $\mathrm{Y}$ & $\mathrm{Y}$ & $\mathrm{Y}$ & $\mathrm{Y}$ \\
\hline Observations & 1,354 & 1,354 & 1,354 & 1,386 & 1,400 \\
\hline Pseudo- $R^{2}$ & .009 & -.063 & -.093 & .012 & .013 \\
\hline$p$-value & .000 & .000 & .000 & .000 & .000 \\
\hline
\end{tabular}

Note.-Standard errors in parentheses.

$* p<.105$.

$* * \quad p<.05$.

$* * * \quad p<.01$.

higher levies spend approximately 3 percent less of their time lobbying (about 11 percent of the mean) than others. At the same time, these entrepreneurs allocate 4.4 percent more of their time at work on management (about 7.4 percent of the mean) than others. The estimation results shown in table 5 are consistent with the prediction of hypothesis 2 . Thus, this result confirms that political connections may increase firm-level efficiency for lobbying activities and reduce the marginal inputs of lobbying efforts when property rights are violated.

\section{Firm Characteristics, Property Rights, and Time Allocation}

In this subsection, we further analyze how the age and size of firms affect entrepreneurs' lobbying efficiency under weak property rights protection. First, entrepreneurs of older firms may have accumulated more connections with local governments than entrepreneurs of younger firms. These connections may also increase firm-level lobbying efficiency for protect- 
ing each firm's property rights. Therefore, we expect that, everything else being equal, entrepreneurs of older firms may spend less time in lobbying against property rights violation. Second, the size of the firm may matter. Under the regionally decentralized authoritarian regime in China, competition between regional officials at the same level is an essential part of the cadre management system (Xu 2011). Larger firms may have higher value for local governments, which may help entrepreneurs to bargain with local governments when high levies are imposed. Economic growth and social stability are the most important performance assessment criteria for local-government officers in the economic-reform era. When a region has higher economic growth and fewer social conflicts, the head of the region will enjoy greater power and have higher chances of being promoted (Xu 2011). Larger firms that can contribute more to local GDP and provide more jobs to local communities are thus of higher value for localgovernment officers. Therefore, the lobbying efficiency of large-firm entrepreneurs may be higher than that of the others.

The specification of the regression models is

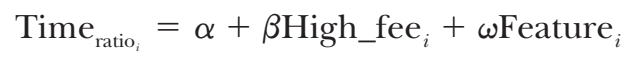

$$
\begin{aligned}
& +\eta\left(\text { Feature }_{i} \times \text { High_fee }{ }_{i}\right)+d X_{i}^{\prime}+\varepsilon_{i},
\end{aligned}
$$

where Feature $_{i}$ refers to the characteristics of firm $i$, including firm age and firm size; Feature ${ }_{i} \times$ High_fee $_{i}$ is the interaction term between the characteristics of firm $i$ and the levy imposed on firm $i$; and $X_{i}^{\prime}$ is a vector of control variables.

Table 6 reports the estimation results. Columns 1-3 present the effects of firm age and the interaction term between firm age and High_fee. Columns 4-6 report the effects of firm size and its interaction term. Column 2 of table 6 shows that the relationship between High_fee and Lobby_Rt remains positive and significant. The interaction term Firm_age $\times$ High_ fee is negatively and significantly correlated with Lobby_Rt, whereas no statistically significant relationship is observed between Firm_age and Lobby_Rt. These results imply that among all the entrepreneurs who are charged high levies, those with older firms spend a smaller proportion of working time in lobbying than others did. Column 3 shows a significant reduction in Mng_Rt associated with High_fee, whereas Firm_age and Firm_age $\times$ High_fee have no significant impact on management time. The results of columns 1-3 suggest that firm age may affect the sensitivity of entrepreneurs' lobbying efforts to property rights violation, because when firms grow older, entrepreneurs accumulate more connections with local governments, which complement their lobbying activities. However, firm age has no significant impact on the sensitivity of their management efforts to property rights violation.

Exploring the features of firm sizes, column 5 of table 6 shows that both High_fee and Firm_size are positively and significantly correlated with 


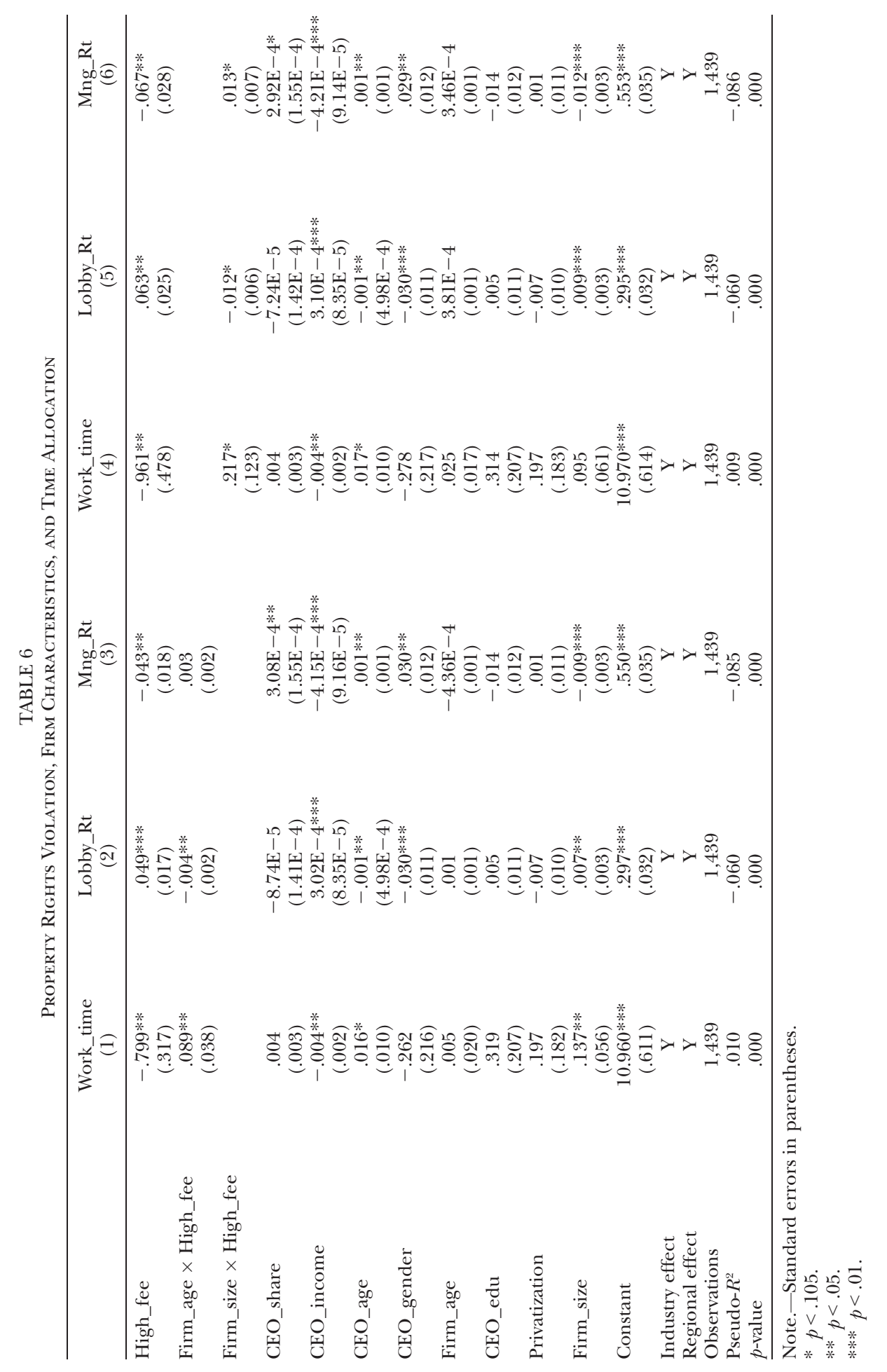


Lobby_Rt. The relationship between Firm_size $\times$ High_fee and Lobby_Rt is negative and significant. As to the impact on management time, column 6 shows that both High_fee and Firm_size are negatively and significantly correlated with Mng_Rt, whereas Firm_size $\times$ High_fee is positively and significantly associated with Mng_Rt. These results reconfirm our earlier estimations that weaker property rights protection induces entrepreneurs to exert more effort toward lobby activities and reduce the proportion of time allocated to management activities. The larger the firm, the more lobbying effort is required, because the stakes of protecting property rights are higher. However, when the firm is larger, the value of the firm to the local government may be higher. Consistent with our predictions, when high levies are imposed on a firm, firm size may moderate the relationship between the property rights violation and time allocation at work. That is, under weaker property rights protection, the higher the value of a firm is to local governments, the more likely the entrepreneur of the firm has more bargaining power with local governments. Hence, this condition increases lobbying efficiency, and the entrepreneur may reduce lobbying time and save more time to deal with daily management activities.

\section{Conclusion}

This study contributes to the literature by providing systematic microevidence on the effects of institutions on entrepreneurs' time or effort allocation, particularly on the effects of the violation of property rights on entrepreneurs' effort allocation. To our knowledge, the empirical evidence we provide on the interactions between institutions and entrepreneur allocation of working effort is the first of its type in the literature. This study analytically extends Becker's (1965) model by adding institutional constraints. This framework allows us to analyze a concrete mechanism, both theoretically and empirically, for why the violation of property rights reduces firm efficiencies (e.g., North 1981; Acemoglu and Johnson 2005).

Employing a nationwide random-sample survey of more than 3,000 entrepreneurs in over 100 cities, we find microevidence that when the government violates private property rights by imposing high arbitrary fees, entrepreneurs spend more time lobbying the government for protection, substantially reducing their management time. Moreover, politically connected entrepreneurs are better protected than others, such that they spend less time lobbying and are able to focus more on management activities. Overall, we find that entrepreneurs have to exert extra effort in dealing with institutional obstacles, at a cost to their time and effort for management activities. Although the findings of this study are based on contemporary Chinese data, our discovery is general. This study confirms Adam Smith's ([1776] 1981) famous proposition that weak property rights hinder entrepreneurship. 
Appendix

TABLE A1

Variable Definitions

\begin{tabular}{|c|c|}
\hline Variable & Definition \\
\hline \multicolumn{2}{|c|}{$\begin{array}{l}\text { Time allocation of the } \\
\text { entrepreneur: }\end{array}$} \\
\hline Work_time & $\begin{array}{l}\text { Average working hours per day in the recent months } \\
\text { reported by the entrepreneur, including learning } \\
\text { time, lobbying time, and management time }\end{array}$ \\
\hline Lobby_hour & $\begin{array}{l}\text { Average time spent by the entrepreneur to deal with } \\
\text { networking activities in the recent months reported } \\
\text { by the entrepreneur }\end{array}$ \\
\hline Mng_hour & $\begin{array}{l}\text { Average time spent by the entrepreneur to deal with } \\
\text { management and other administrative activities } \\
\text { of the firm in the recent months reported by the } \\
\text { entrepreneur }\end{array}$ \\
\hline Study_hour & $\begin{array}{l}\text { Average time spent by the entrepreneur on learning in } \\
\text { the recent months reported by the entrepreneur }\end{array}$ \\
\hline Lobby_Rt & Lobby_hour/Work_time \\
\hline Mng_Rt & Mng_hour/Work_time \\
\hline \multicolumn{2}{|c|}{ Property rights violation: } \\
\hline Forced_fee & $\begin{array}{l}\text { Total additional levies imposed on the firm in the } \\
\text { previous financial year }\end{array}$ \\
\hline High_fee & $\begin{array}{l}\text { Dummy variable that equals } 1 \text { if the ratio of the } \\
\text { Forced_fee to total sales of the previous year is in the } \\
\text { top } 25 \text { percent, } 0 \text { otherwise }\end{array}$ \\
\hline \multicolumn{2}{|c|}{$\begin{array}{l}\text { Political connections of the } \\
\text { entrepreneur: }\end{array}$} \\
\hline $\mathrm{CPC}$ & $\begin{array}{l}\text { Dummy variable that equals } 1 \text { if the entrepreneur was a } \\
\text { CPC member at the time of the survey, } 0 \text { otherwise }\end{array}$ \\
\hline \multicolumn{2}{|c|}{ Entrepreneur characteristics: } \\
\hline CEO_share & $\begin{array}{l}\text { Ownership held by the entrepreneur divided by total } \\
\text { equity of the firm in the previous financial year }\end{array}$ \\
\hline CEO_age & Age of the entrepreneur in year at the time of the survey \\
\hline CEO_edu & $\begin{array}{l}\text { Dummy variable that equals } 1 \text { if the entrepreneur has } \\
\text { high school education or above at the time of the } \\
\text { survey, } 0 \text { otherwise }\end{array}$ \\
\hline CEO_gender & $\begin{array}{l}\text { Dummy variable that equals } 1 \text { if the entrepreneur is a } \\
\text { female, } 0 \text { otherwise }\end{array}$ \\
\hline CEO_income & $\begin{array}{l}\text { Total income the entrepreneur gained from the firm in } \\
\text { the previous financial year }\end{array}$ \\
\hline \multicolumn{2}{|l|}{ Firm characteristics: } \\
\hline Firm_age & Age of the firm in years at the time of the survey \\
\hline Firm_size & $\begin{array}{l}\text { Total number of employees of the firm in logarithm } \\
\text { form }\end{array}$ \\
\hline Privatization & $\begin{array}{l}\text { Dummy variable that equals } 1 \text { if the private firm was } \\
\text { privatized from a former state-owned enterprise, } \\
0 \text { otherwise }\end{array}$ \\
\hline \multicolumn{2}{|c|}{ Instrumental variables: } \\
\hline Anti-Corruption & $\begin{array}{l}\text { Number of registered cases under the direct investiga- } \\
\text { tion of people's procuratorates, divided by provincial } \\
\text { population (cases per } 10,000 \text { persons) in the } 2 \text { years } \\
\text { before the survey }\end{array}$ \\
\hline CVRG & $\begin{array}{l}\text { Frequency of the appearance of the keyword "nonpublic- } \\
\text { sector development" in articles written by } \\
\text { the party chief of a specified province in the } 2 \text { years } \\
\text { before the survey and covered by the Database of } \\
\text { Chinese Communist Party Construction Periodicals }\end{array}$ \\
\hline
\end{tabular}




\section{References}

Acemoglu, Daron. 1995. "Reward Structures and the Allocation of Talent." European Econ. Rev. 39 (1): 17-33.

Acemoglu, Daron, and Simon Johnson. 2005. "Unbundling Institutions." J.P.E. 113 (5): 949-95.

Acemoglu, Daron, Simon Johnson, and James A. Robinson. 2001. "The Colonial Origins of Comparative Development: An Empirical Investigation.” A.E.R. 91 (5): 1369-1401.

- 2005. "Institutions as a Fundamental Cause of Development." In Handbook of Economic Growth. Vol. 1A, edited by Philippe Aghion and Steven Durlauf, 385-472. Amsterdam: North-Holland.

Akerlof, George A., and Rachel E. Kranton. 2005. "Identity and the Economics of Organizations.” J. Econ. Perspectives 19 (1): 9-32.

Baumol, William J. 1990. "Entrepreneurship: Productive, Unproductive, and Destructive." J.P.E. 98 (5): 893-921.

Becker, Gary S. 1965. “A Theory of the Allocation of Time.” Econ.J. 75 (299): 493517.

Benz, Matthias, and Bruno Frey. 2004. "Being Independent Raises Happiness at Work.” Swedish Econ. Policy Rev. 11 (2): 95-134.

Besley, Timothy. 1995. "Property Rights and Investment Incentives: Theory and Evidence from Ghana." J.P.E. 103 (5): 903-37.

Brown, G. 1998. "Budgets, Cadres and Local State Capacity in Rural Jiangsu" in Village Inc.: Chinese Rural Society in the 1990s, edited by Flemming Christiansen and Junzuo Zhang, 22-47. London: Curzon.

Clark, Andrew. 1997. "Job Satisfaction and Gender: Why Are Women So Happy at Work?” Labour Econ. 4 (4): 341-72.

Clarke, Donald C., Peter Murrell, and Susan H. Whiting. 2008. "The Role of Law in China's Economic Development." In China's Great Economic Transformation, edited by Loren Brandt and Thomas G. Rawski, 375-428. Cambridge: Cambridge Univ. Press.

Coase, Ronald. 1991. "The Institutional Structure of Production: Lecture to the Memory of Alfred Nobel." http:/ /www.nobelprize.org/nobel_prizes/economic -sciences/laureates/1991/coase-lecture.html.

Cole, Matthew A., Robert J. R. Elliott, and Jing Zhang. 2009. "Corruption, Governance and FDI Location in China: A Province-Level Analysis." J. Development Studies 45 (9): 1494-1512.

Cooper, Arnold, Mohan Ramachandran, and David Schoorman. 1997. "Time Allocation Patterns of Craftsmen and Administrative Entrepreneurs: Implications for Financial Performance." Entrepreneurship Theory and Practice 22 (2): 123-36.

Cull, Robert, and Lixin Colin Xu. 2005. "Institutions, Ownership, and Finance: the Determinants of Profit Reinvestment among Chinese Firms." J. Financial Econ. 77 (1): 117-46.

Dewatripont, Mathias, Ian Jewitt, and Jean Tirole. 1999. "The Economics of Career Concerns, Part II: Application to Missions and Accountability of Government Agencies." Rev. Econ. Studies 66 (1): 199-217.

- 2000. "Multitask Agency Problems: Focus and Task Clustering." European Econ. Rev. 44: 4-6.

Fan, Joseph P. H., T.J. Wong, and Tianyu Zhang. 2007. "Politically Connected CEOs, Corporate Governance, and Post-IPO Performance of China's Newly Partially Privatized Firms." J. Financial Econ. 84 (2): 330-57.

Fehr, Ernst, and Armin Falk. 2002. "Psychological Foundations of Incentives." European Econ. Rev. 46 (4): 687-724. 
Fischer, E., and R. Reuber. 1997. "The Good, the Bad, and the Unfamiliar: The Challenges of Reputation Formation Facing New Firms.” Entrepreneurship Theory and Practice 31 (1): 53-75.

Francis, Bill B., Iftekhar Hasan, and Xian Sun. 2009. "Political Connections and the Process of Going Public: Evidence from China." J. Int. Money and Finance 28 (4): 696-719.

Freeman, Richard B. 1997. "Working for Nothing: The Supply of Volunteer Labor." J. Labor Econ. 15 (1): 140-66.

Guo, Di, Kun Jiang, Byongyang Kim, and Chenggang, Xu. 2014. "Political Economy of Private Firms in China." J. Comparative Econ. 42 (2): 286-303.

Holmstrom, Bengt, and Paul Milgrom. 1991. "Multitask Principal-Agent Analyses: Incentive Contracts, Asset Ownership, and Job Design.” J. Law Econ. and Organization 7: 24-52.

Johnson, Simon, John McMillan, and Christopher Woodruff. 2002. "Property Rights and Finance." A.E.R. 92 (5): 1335-56.

Klapper, Leora F., and Inessa Love. 2004. "Corporate Governance, Investor Protection, and Performance in Emerging Markets." J. Corporate Finance 10 (5): 703-28.

La Porta, Rafael, Florencio Lopez-de-Silanes, Andrei Shleifer, and Robert Vishny. 2000. "Investor Protection and Corporate Governance." J. FinancialEcon. 58 (1): $3-27$.

Li, Hongbin, Lingsheng Meng, Qian Wang, and Li-an Zhou. 2008. "Political Connections, Financing and Firm Performance: Evidence from Chinese Private Firms." J. Development Econ. 87 (2): 283-99.

Lin, Chen, Ping Lin, and Hong Zou. 2012. "Does Property Rights Protection Affect Corporate Risk Management Strategy? Intra- and Cross-Country Evidence." J. Corporate Finance 18 (2): 311-30.

Locke, John. [1689] 1823. Two Treatises of Government. Vol. 5 of The Works of John Locke. London: Thomas Tegg.

Lucas, Robert E., Jr., and Benjamin Moll. 2011. "Knowledge Growth and the Allocation of Time." Working Paper no. 17495 (October), NBER, Cambridge, MA.

McCarthy, A. M., Krueger, D. A., and T. S. Schoenecker 1990. "Changes in the Time Allocation Patterns of Entrepreneurs." Entrepreneurship Theory and Practice 15 (2): 7-18.

North, Douglass D. 1981. Structure and Change in Economic History. New York: Norton.

Peng, Mike W., and Yadong Luo. 2000. "Managerial Ties and Firm Performance in a Transition Economy: The Nature of a Micro-Macro Link." Acad. Management J. 43 (3): 486-501.

Pollak, Robert A., and Michael L. Wachter. 1975. "Allocation of Time." J.P.E. 83 (2): 255-78.

Smith, Adam. [1776] 1981. An Inquiry into the Nature and Causes of the Wealth of Nations. Indianapolis, IN: Liberty Fund.

Tullock, Gordon. 1967. "The Welfare Costs of Tariffs, Monopolies, and Theft." Western Econ. J. 5 (3): 224-32.

Verheul, Ingrid, Martin Carree, and Roy Thurik. 2009. "Allocation and Productivity of Time in New Ventures of Female and Male Entrepreneurs.” Small Bus. Econ. 33 (3): 273-91.

Wong, Christine P. W., ed. 1997. Financing Local Government in the People's Republic of China. Hong Kong: Oxford Univ. Press.

$\mathrm{Xu}$, Chenggang. 2011. "The Fundamental Institutions of China's Reforms and Development.” J. Econ. Literature. 49 (4): 1076-1151. 